\title{
Planifilum yunnanense sp. nov., a thermophilic thermoactinomycete isolated from a hot spring
}

Correspondence

Biao Shen

shenbiao@njau.edu.cn

\author{
Yan-xin Zhang, Chen Dong and Shen Biao
}

Key Laboratory of Microbiological Engineering of Agricultural Environment, College of Life Sciences, Nanjing Agricultural University, Nanjing 210095, China

\begin{abstract}
A thermophilic actinomycete, strain $\mathrm{LA} 5^{\top}$, was isolated from a hot spring in Yunnan province, People's Republic of China. The isolate grew aerobically at temperatures of $50-75{ }^{\circ} \mathrm{C}$. Aerobic mycelia were not observed. Single spores were produced along the substrate hypha. Strain $\mathrm{LA} 5^{\top}$ was characterized chemotaxonomically by having MK-7 as the predominant menaquinone and iso- $\mathrm{C}_{17: 0}(27.7 \%)$ and $\mathrm{C}_{16: 0}(22.4 \%)$ as the major fatty acids. The cell wall contained meso-diaminopimelic acid. The DNA G+C content was 56.8 mol\%. Phylogenetic analyses based on 16S rRNA gene sequences indicated that strain $\mathrm{LA}^{\top}{ }^{\top}$ belongs to the genus Planifilum. Levels of DNA-DNA relatedness between strain $\mathrm{LA}^{\top}$ and Planifilum fimeticola $\mathrm{H}_{0165^{\top}}$ and Planifilum fulgidum $500275^{\top}$ were 43.6 and $52.7 \%$, respectively. On the basis of phenotypic properties and phylogeny, strain $L A 5^{\top}$ represents a novel species of the genus Planifilum, for which we propose the name Planifilum yunnanense sp. nov., with the type strain

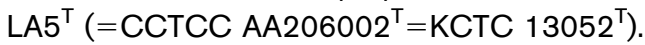

Only one genus, Thermoactinomyces, was included in the family 'Thermoactinomycetaceae' before 2005. Yoon et al. (2005) suggested that the family 'Thermoactinomycetaceae' should be divided into four genera, Laceyella, Thermoactinomyces sensu stricto, Thermoflavimicrobium and Seinonella, based on 16S rRNA gene sequence analysis as well as chemotaxonomic and physiological characteristics of recognized Thermoactinomyces species. In addition, Hatayama et al. (2005) proposed a new genus Planifilum with two species.

Strain $\mathrm{LA}^{\mathrm{T}}$ was isolated from a hot spring in Yunnan province, People's Republic of China. It could grow at temperatures of $50-75{ }^{\circ} \mathrm{C}$, the highest growth temperature obtained for all Thermoactinomyces strains reported so far, with optimum growth occurring at $60-70{ }^{\circ} \mathrm{C}$. Colonies of 3-4 $\mathrm{mm}$ in diameter appeared after $48 \mathrm{~h}$ incubation on LB Gelrite plates at $70{ }^{\circ} \mathrm{C}$. The colonies were cream-yellow with radial wrinkles. No aerobic mycelia were observed. Single spores were produced along the substrate hypha. Strain $\mathrm{LA} 5^{\mathrm{T}}$ did not produce any diffusible pigment during the whole incubation period. Strain $\mathrm{LA} 5^{\mathrm{T}}$ grew at $\mathrm{pH}$ 6-10, with optimum growth at $\mathrm{pH} 8.5$.

To establish accurately the phylogenetic position of strain $\mathrm{LA} 5^{\mathrm{T}}$, its $16 \mathrm{~S}$ rRNA gene sequence was determined. Genomic DNA extraction and PCR amplification of $16 \mathrm{~S}$ rRNA genes using universal primers were performed by using the method of Ausubel et al. (1999). The resultant sequence for strain $\mathrm{LA}^{\mathrm{T}}$ was aligned manually against

The GenBank/EMBL/DDBJ accession number for the 16S rRNA gene sequence of strain $L A 5^{\top}$ is DQ119659. sequences obtained from GenBank. Phylogenetic trees were inferred using minimum-evolution, maximum-parsimony and neighbour-joining methods (Kumar et al., 2004). The bootstrap values of the neighbour-joining tree were calculated based on 1000 repeats.

The results of alignment with 16S rRNA gene sequences obtained from GenBank showed that strain LA5 ${ }^{\mathrm{T}}$ had similarities of 99 and $97 \%$ with Planifilum fulgidum $500275^{\mathrm{T}}$ and Planifilum fimeticola $\mathrm{H} 0165^{\mathrm{T}}$, respectively, and less than $94 \%$ with any others used. In the phylogenetic trees constructed using three different methods, strain $\mathrm{LA} 5^{\mathrm{T}}$ and members of the genus Planifilum formed an independent cluster in the family 'Thermoactinomycetaceae'. Strain $\mathrm{LA} 5^{\mathrm{T}}$ was most closely related to $P$. fulgidum $500275^{\mathrm{T}}$, as shown in the neighbour-joining tree (Fig. 1). Therefore, strain $\mathrm{LA}^{\mathrm{T}}$ should be classified in the genus Planifilum.

The DNA base composition of strain $\mathrm{LA} 5^{\mathrm{T}}$ was determined by using the thermal denaturation method (Marmur \& Doty, 1962), with Escherichia coli $\mathrm{K}-12$ as reference (DNA G $+\mathrm{C}$ content, $50 \mathrm{~mol} \%$ ). The DNA G $+\mathrm{C}$ content was calculated by using the method of De Ley (1970). The results showed that the DNA G $+\mathrm{C}$ content of strain $\mathrm{LA} 5^{\mathrm{T}}$ was $56.8 \mathrm{~mol} \%$, close to the values obtained for $P$. fulgidum $500275^{\mathrm{T}}$ (60.0 mol\%) and P. fimeticola $\mathrm{H} 0165^{\mathrm{T}}$ (60.3 mol\%), but much higher than those of other members of the family 'Thermoactinomycetaceae', which also indicated that strain $\mathrm{LA} 5^{\mathrm{T}}$ was closely related to the genus Planifilum.

In order to determine further the relationship between strain $\mathrm{LA} 5^{\mathrm{T}}$ and other members of the genus Planifilum 


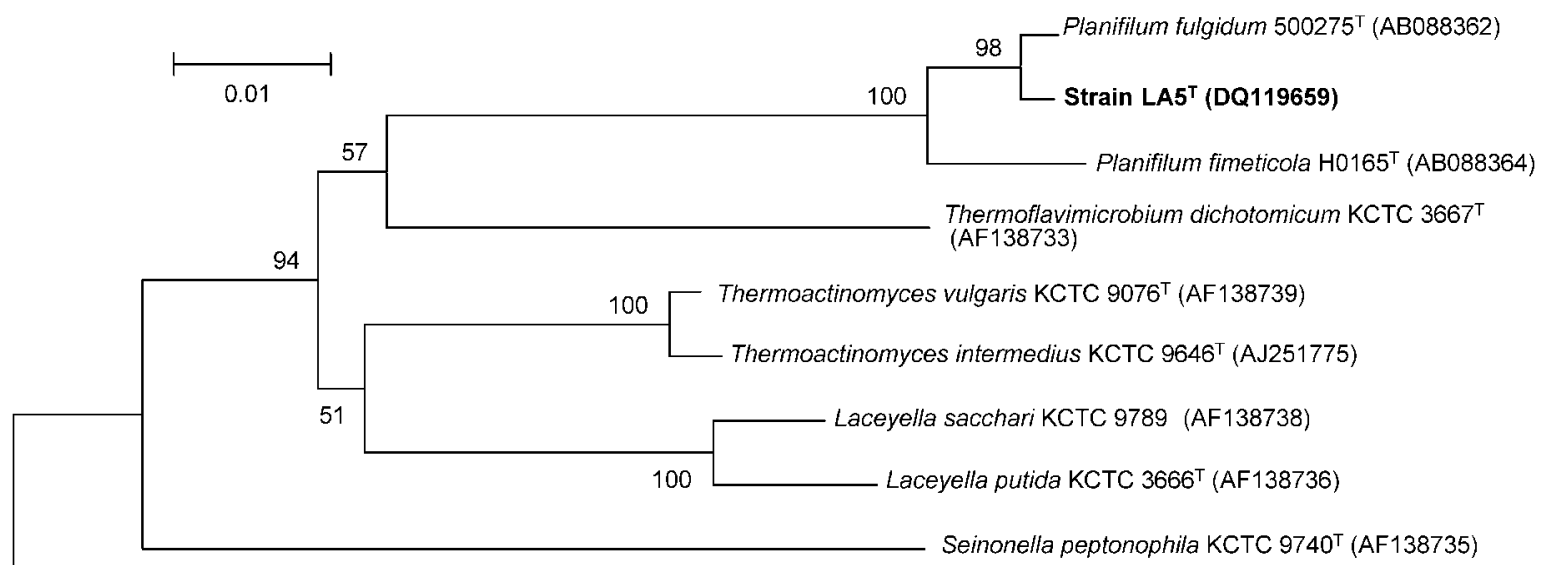

Bacillus subtilis DSM 618 (DA529249)

Fig. 1. Neighbour-joining phylogenetic tree based on $16 \mathrm{~S}$ rRNA gene sequences of strain $L A 5^{\top}$, members of the family 'Thermoactinomycetaceae' and Bacillus subtilis DSM 618. Numbers at nodes are percentage bootstrap values based on 1000 repeats (only values greater than $50 \%$ are shown). Bar, 0.01 substitutions per nucleotide position.

phylogenetically, DNA-DNA hybridizations of strain LA $5^{\mathrm{T}}$ with P. fulgidum $500275^{\mathrm{T}}$ and P. fimeticola $\mathrm{H} 0165^{\mathrm{T}}$ were respectively performed by using thermal denaturation and reassociation (De Ley et al., 1970). A UV spectrophotometer (Lambda 35; Perkin Elmer) and temperature controller (PTP-6; Perkin Elmer) were used. Levels of DNA-DNA relatedness between strain $\mathrm{LA}^{\mathrm{T}}$ and $P$. fimeticola $\mathrm{H} 0165^{\mathrm{T}}$ and P. fulgidum $500275^{\mathrm{T}}$ were only 43.6 and $52.7 \%$, respectively. Therefore, strain $\mathrm{LA}^{\mathrm{T}}$ represents a novel species of the genus Planifilum.

The chemotaxonomic characteristics of strain $\mathrm{LA}^{\mathrm{T}}$ were determined using cells cultured in LB medium, supplemented with starch. Cell walls were analysed for principal amino acids by using the method of Lechevalier \& Lechevalier (1970). Whole-cell sugars were determined using GC and MS (GC-MS model HP-6890; Hewlett Packard) according to the methods of Saddler et al. (1991) and Takahashi \& Egusa (1992). Cellular fatty acids were analysed using HP-6890 GC, equipped with a hydrogen flame-ionization detector (FID) and HP Chemstation (version A 5.01), based on the method of Collins (1985). The results revealed the presence of meso-diaminopimelic acid, alanine and glutamic acid, indicating that the cell wall chemotype was type III, consistent with all other members of the family 'Thermoactinomycetaceae'. MK-7 was the predominant menaquinone. Whole-cell sugars were found to be glucose and ribose, without any diagnostic sugars. The predominant fatty acids were iso- $\mathrm{C}_{17: 0}(27.7 \%), \mathrm{C}_{16: 0}$ $(22.4 \%)$, iso- $\mathrm{C}_{16: 0}(8.8 \%)$ and anteiso- $\mathrm{C}_{17: 0}(8.6 \%)$, which were different from those of the type strains of species of all five genera in the family 'Thermoactinomycetaceae' (Table 1).
Utilization of sugars and other substrates was tested using the following medium $\left(\mathrm{g} \mathrm{l}^{-1}\right):\left(\mathrm{NH}_{4}\right)_{2} \mathrm{SO}_{4}, 1.5 ; \mathrm{KH}_{2} \mathrm{PO}_{4}$, $0.5 ; \mathrm{K}_{2} \mathrm{HPO}_{4} .3 \mathrm{H}_{2} \mathrm{O}, 1.5 ; \mathrm{MgSO}_{4} .7 \mathrm{H}_{2} \mathrm{O}, 0.2 ; \mathrm{NaCl}, 0.5$; yeast extract, 0.02 ; at $65{ }^{\circ} \mathrm{C}$ and $\mathrm{pH}$ 8.5. Strain $\mathrm{LA} 5^{\mathrm{T}}$ could utilize many sugars, organic acids and amino acids as sole carbon sources and showed a greater range of substrate utilization than P. fimeticola $\mathrm{H}_{0165^{\mathrm{T}}}$ and P. fulgidum $500257^{\mathrm{T}}$ (Table 1). Strain $\mathrm{LA} 5^{\mathrm{T}}$ grew on $\mathrm{LB}$, potato dextrose agar, Czapek and starch-casein, but only weak growth was observed on glycerol-asparagine and Gause's synthetic medium.

\section{Description of Planifilum yunnanense sp. nov.}

Planifilum yunnanense (yun.nan.en'se. N.L. neut. adj. Yunnanense referring to Yunnan, the southern Province, P. R. China, where the sample was collected).

Colonies are rough and cream-yellow with radial wrinkles. Growth occurs at $50-75{ }^{\circ} \mathrm{C}$ (optimum growth at $60-70{ }^{\circ} \mathrm{C}$ ) and $\mathrm{pH}$ 6.0-10.0 (optimum growth at $\mathrm{pH}$ 8.5). Casein, glutin and starch are degraded. Predominant fatty acids are iso- $\mathrm{C}_{17: 0}(27.7 \%)$ and $\mathrm{C}_{16: 0}(22.4 \%)$. The DNA $\mathrm{G}+\mathrm{C}$ content of the type strain is $56.8 \mathrm{~mol} \%$.

The type strain, $\mathrm{LA5}^{\mathrm{T}} \quad\left(=\mathrm{CCTCC}\right.$ AA206002 ${ }^{\mathrm{T}}=$ KCTC $13052^{\mathrm{T}}$ ), was isolated from a hot spring in Yunnan Province, P. R. China.

\section{Acknowledgements}

The authors would like to thank Professor Akira Nakamura (University of Tsukuba, Japan) for kindly providing $P$. fulgidum $500275^{\mathrm{T}}$ and $P$. fimeticola $\mathrm{H} 0165^{\mathrm{T}}$. We also thank Dr Shu-Kun Tang (Yunnan University, China) for analysis of cell-wall components and Dr Xinhua Chen (China Agricultural University, China) for DNA-DNA hybridization. 
Table 1. Phenotypic characteristics of strain $\mathrm{LA} 5^{\top}$ and recognized Planifilum species

Strains: 1, P. fimeticola ${\mathrm{H} 0165^{\mathrm{T}}}^{\mathrm{T}}$; 2, P. fulgidum $500257^{\mathrm{T}}$; 3, strain LA5 ${ }^{\mathrm{T}}$ (Planifilum yunnanense sp. nov.). +, Positive reaction; -, negative reaction; NO, not observed. All strains can use the following substrates as carbon sources: casein, glutin and starch, $\alpha$-cyclodextrin, D-fructose, maltose, Dmannitol, D-raffinose, D-melibiose, turanose, D-gluconic acid, $\beta$-hydroxybutyric acid, $\gamma$-hydroxybutyric acid, $\alpha$-ketovaleric acid, malonic acid, propionic acid, acetic acid, cis-aconitic acid, D-alanine and L-alanine.

\begin{tabular}{|c|c|c|c|}
\hline Characteristic & 1 & 2 & 3 \\
\hline Aerial mycelium ${ }^{\star}$ & NO & NO & NO \\
\hline Optimum growth temperature $\left({ }^{\circ} \mathrm{C}\right)^{*}$ & $55-63$ & $60-65$ & $60-70$ \\
\hline Predominant menaquinone ${ }^{\star}$ & MK-7 & MK-7 & MK-7 \\
\hline Major fatty acids* & $\begin{array}{l}\text { iso- } \mathrm{C}_{16: 0}, \text { iso- } \mathrm{C}_{17: 0} \\
\text { anteiso- } \mathrm{C}_{17: 0}\end{array}$ & $\begin{array}{l}\text { iso- } \mathrm{C}_{17: 0} \text {, anteiso- } \mathrm{C}_{17: 0} \\
\text { iso- } \mathrm{C}_{15: 0}\end{array}$ & $\begin{array}{l}\text { iso- }_{17: 0}, \mathrm{C}_{16: 0} \\
\text { iso- } \mathrm{C}_{16: 0} \text {, anteiso- } \mathrm{C}_{17: 0}\end{array}$ \\
\hline D-Raffinose & + & - & + \\
\hline Trehalose & + & - & - \\
\hline Gentiobiose & - & - & + \\
\hline Lactose & + & - & + \\
\hline Sucrose & - & + & + \\
\hline D-Arabinose & + & + & - \\
\hline D-Psicose & - & + & + \\
\hline myo-Inositol & - & - & + \\
\hline i-Erythritol & - & + & + \\
\hline D-Sorbitol & + & - & + \\
\hline Xylitol & + & + & - \\
\hline$N$-Acetyl-D-glucosamine & - & - & + \\
\hline Methyl $\beta$-D-glucoside & - & + & + \\
\hline Succinic acid monomethyl ester & - & - & + \\
\hline D-Galacturonic acid & - & - & + \\
\hline$\alpha$-Hydroxybutyric acid & - & + & - \\
\hline$p$-Hydroxyphenylacetic acid & - & - & + \\
\hline L-Proline & - & + & + \\
\hline L-Threonine & + & - & + \\
\hline L-Tyrosine & + & - & - \\
\hline Inosine & + & - & + \\
\hline Uridine & - & - & + \\
\hline
\end{tabular}

${ }^{*}$ Data for P. fimeticola and P. fulgidum are from Hatayama et al. (2005).

\section{References}

Ausubel, F. M., Brent, R., Kingston, R. E., Moore, D. D., Seidman, J. G., Smith, J. A. \& Struhl, K. (1999). Short Protocols in Molecular Biology, 4th edn. John Wiley \& Sons.

Collins, M. D. (1985). Isoprenoid quinone analysis in bacterial classification and identification. In Chemical Methods in Bacterial Systematics, pp. 267-287. London: Academic Press.
De Ley, J. (1970). Reexamination of the association between melting point, buoyant density, and chemical base composition of DNA. $J$ Bacteriol 101, 738-754.

De Ley, J., Cattoir, H. \& Reynaerts, A. (1970). The quantitative measurement of DNA hybridization from renaturation rates. Eur $J$ Biochem 12, 133-142.

Hatayama, K., Shoun, H., Ueda, Y. \& Nakamura, A. (2005). Planifilum fimeticola gen. nov., sp. nov. and Planifilum fulgidum sp. nov., novel 
members of the family 'Thermoactinomycetaceae' isolated from compost. Int J Syst Evol Microbiol 55, 2101-2104.

Kumar, S., Tamura, K. \& Nei, M. (2004). MEGA3: integrated software for Molecular Evolutionary Genetics Analysis and sequence alignment. Brief Bioinform 5, 150-163.

Lechevalier, M. P. \& Lechevalier, H. (1970). Chemical composition as a criterion in the classification of aerobic actinomycetes. Int J Syst Bacteriol 20, 435-443.

Marmur, J. \& Doty, P. (1962). Determination of the base composition of deoxyribonucleic acid from its thermal denaturation temperature. J Mol Biol 5, 109-118.
Saddler, G. S., Tavecchia, P., Lociure, S., Zanol, M., Colombo, L. \& Selva, E. (1991). Analysis of madurose and other actinomycete whole cell sugars by gas chromatography. J Microbiol Methods 14, 185-191.

Takahashi, Y. \& Egusa, H. (1992). Quantitative analysis for madurose and other sugars in small amount of actinomycete whole cells by gasliquid chromatography. Actinomycetologica 6, 69-78.

Yoon, J.-H., Kim, I.-G., Shin, Y.-K. \& Park, Y.-H. (2005). Proposal of the genus Thermoactinomyces sensu stricto and three new genera, Laceyella, Thermoflavimicrobium and Seinonella, on the basis of phenotypic, phylogenetic and chemotaxonomic analyses. Int J Syst Evol Microbiol 55, 395-400. 